\title{
Intra- and interspecific niche partitioning in striped and common dolphins inhabiting the southwestern Mediterranean Sea
}

\author{
Joan Giménez ${ }^{1, *}$, Ana Cañadas ${ }^{2}$, Francisco Ramírez ${ }^{1}$, Isabel Afán ${ }^{3}$, \\ Susana García-Tiscar ${ }^{4}$, Carolina Fernández-Maldonado ${ }^{5}$, Juan José Castillo ${ }^{6}$, \\ Renaud de Stephanis ${ }^{7}$
}

\footnotetext{
${ }^{1}$ Department of Conservation Biology, Estación Biológica de Doñana - Consejo Superior de Investigaciones Científicas (EBD-CSIC), Américo Vespucio s/n, Isla de la Cartuja, 41092 Seville, Spain

${ }^{2}$ Alnilam Research and Conservation, Pradillos 29, 28491 Navacerrada, Madrid, Spain

${ }^{3}$ Laboratorio de SIG y Teledetección (LAST), Estación Biológica de Doñana - Consejo Superior de Investigaciones Científicas (EBD-CSIC), Americo Vespucio s/n, Isla de la Cartuja, 41092 Seville, Spain

${ }^{4}$ Department of Ecology, Universidad Autónoma de Madrid, Ciudad Universitaria de Cantoblanco, 28049 Madrid, Spain

${ }^{5}$ Agencia de Medio Ambiente y Agua de Andalucía, Consejería de Medio Ambiente y Ordenación del Territorio, Junta de Andalucía, Johann G. Gutenberg 1, Isla de la Cartuja, 41092 Seville, Spain

${ }^{6}$ Centro de Recuperación de Especies Marinas Amenazadas (CREMA), Aula del Mar de Málaga, Pacífico 80, 29004 Málaga, Spain

${ }^{7}$ Conservation, Information and Research on Cetaceans (CIRCE), Cabeza de Manzaneda 3, Algeciras-Pelayo, 11390 Cádiz, Spain
}

\begin{abstract}
Community structure and functioning is shaped by resource partitioning between cooccurring species. Niche differentiation among sympatric species can be reached through trophic, spatial or temporal segregation to avoid competitive exclusion. Intraspecific segregation in the use of habitats and resources might determine, in turn, a population's niche width and interspecific segregation. The Alboran Sea is the only area in the Mediterranean where common and striped dolphins coexist abundantly. Therefore, these putative competing species provided the opportunity to investigate niche partitioning through spatial modelling and trophic analysis. Density surface modelling and nitrogen and carbon stable isotopes $\left(\delta^{15} \mathrm{~N}\right.$ and $\left.\delta^{13} \mathrm{C}\right)$ were used to investigate spatial and trophic niche partitioning at inter- and intraspecific levels. The 2 species showed high isotopic overlap. However, we could not rule out the possibility of interspecific trophic segregation, as isotopic similarity does not necessarily mean true ecological or dietary similarity. Among conspecifics, variations in $\delta^{15} \mathrm{~N}$ and $\delta^{13} \mathrm{C}$ values with dolphin length pointed to ontogenetic dietary changes in striped dolphins, while sex played only a minor role in $\delta^{13} \mathrm{C}$ values. Spatially, these species tended to segregate their core areas of distribution, with common dolphins being more coastal than striped dolphins, which occupied adjacent, deeper waters. Overall, the main enabler for the coexistence of common and striped dolphins in the Alboran Sea was spatial segregation.
\end{abstract}

KEY WORDS: Stable isotopes $\cdot$ Spatial modelling $\cdot$ Niche partitioning $\cdot$ Co-occurring species · Segregation $\cdot$ Stenella coeruleoalba $\cdot$ Delphinus delphis

Resale or republication not permitted without written consent of the publisher

\section{INTRODUCTION}

The competitive exclusion principle (Gause 1934), also known as the Gause principle, states that species cannot coexist if they have the same ecological niche. Accordingly, the niche theory predicts that community structure and functioning may be shaped by resource partitioning between co-occurring species 
(Hutchinson 1957). Thus, quantifying niche overlap can be a step towards understanding species coexistence (Geange et al. 2011). Niche differentiation among co-occurring species can be reached through trophic, spatial or temporal segregation to avoid competitive exclusion (Gause 1934, Hutchinson 1957, Pianka 1976). Most differentiation tends to occur along the first 2 dimensions (Schoener 1974). In turn, inter-individual niche variation might be an important driver of population niche widths and, ultimately, of interspecific segregation (Durell 2000, Bolnick et al. 2003, Araújo et al. 2011). Despite this consideration, previous studies typically consider conspecifics as ecological equivalents (e.g. Hutchinson 1957, Colwell \& Futuyma 1971, Abrams 1980), thus neglecting an important aspect of the communities' structure and functioning.

Recent advances in spatial modelling techniques and stable isotope analysis can provide quantitative information on niche partitioning. In particular, density surface modelling allows the production of $2 \mathrm{D}$ density maps for the delimitation of high-density areas (e.g. Cañadas \& Vázquez 2014). Therefore, this technique has the potential to provide an accurate assessment of the spatial segregation of co-occurring species by depicting those hotspots where individuals occur in higher numbers. In addition, stable isotope approaches, commonly based on determinations of carbon and nitrogen isotope ratios (denoted as $\delta^{13} \mathrm{C}$ and $\delta^{15} \mathrm{~N}$ ), may provide quantitative insights into the trophic ecology of individuals and populations, and are thus extremely useful for investigating niche partitioning between co-occurring species and conspecifics (e.g. Méndez-Fernandez et al. 2013, Newsome et al. 2015). Both isotopes used in conjunction reflect what an animal assimilates from its diet and the habitat in which it feeds (Bearhop et al. 2004, Newsome et al. 2007).

Further, stable isotope approaches have been used previously for tracing diet differences among conspecifics, such as ontogenetic shifts (e.g. Arthur et al. 2008, Knoff et al. 2008, Lukeneder et al. 2010) and sex differences (e.g. Forero et al. 2005, Bearhop et al. 2006). Stable isotope approaches may provide, therefore, the necessary means for quantifying the trophic niche overlap/segregation between co-occurring species and identifying those drivers of trophic segregation within species.

In the Mediterranean Sea, the striped dolphin Stenella coeruleoalba is currently the most abundant species, even though its abundance is close to, if not beyond, the carrying capacity of the basin (Aguilar 2000). In contrast, the Mediterranean subpopulation of the common dolphin Delphinus delphis appear to have suffered an abrupt decline over recent decades (Bearzi et al. 2003), and it is listed as Endangered by the IUCN Red List. Nevertheless, the Alboran Sea is the only area in the Mediterranean where common and striped dolphins coexist in high numbers (Bearzi et al. 2003). This provides a unique opportunity to investigate niche partitioning between putative competitor species through spatial modelling and trophic analysis. Although extremely similar in size and shape, differences in the ecological strategies used by these 2 species are found in the North Atlantic (Spitz et al. 2012). Specifically, common dolphins feed on high-quality food with a corresponding high metabolic cost of living, while striped dolphins are characterized by a moderate food quality and metabolic cost of living (Spitz et al. 2012). Here, we used density surface modelling of sighting data and $\delta^{13} \mathrm{C}$ and $\delta^{15} \mathrm{~N}$ from skin biopsies to investigate niche partitioning (considering both the spatial and the trophic dimensions) between species and conspecifics of striped and common dolphins.

\section{MATERIALS AND METHODS}

\section{Study area}

The Alboran Sea is located in the western Mediterranean Sea (Fig. S1 in the Supplement at www.intres.com/articles/suppl/m567p199_supp.pdf). The Alboran basin is characterized by the presence of 2 anticyclonic eddies formed by the surface inflow of Atlantic waters, causing intermittent upwelling and enhancing marine productivity (Arin et al. 2002). These hydrodynamic processes and the complex seafloor topography with steep escarpments, canyons and mountains further serve to concentrate productivity (Rodríguez 1982, Rubín et al. 1992). All of these characteristics turn this area into a highly productive sub-basin compared to the oligotrophic Mediterranean Sea (Rubín et al. 1992, Huertas et al. 2012). Thus, this area hosts a high level of biodiversity (Rodríguez 1982, Gascard \& Richez 1985, Parrilla \& Kinder 1987, Tintoré et al. 1988, Rubín et al. 1992, Templado 1993), particularly in cetaceans (Cañadas 2006).

\section{Stable isotope analysis}

Carbon and nitrogen stable isotopes were used as proxies for habitat use and trophic position, respectively (Post 2002, Bearhop et al. 2004, Newsome et al. 
2007). Typically, $\delta^{13} \mathrm{C}$ provides information on the main sources of primary production incorporated into trophic webs (DeNiro \& Epstein 1978) and may also inform about the inshore versus offshore and benthic versus pelagic consumption (Rubenstein \& Hobson 2004 , Fry 2006), while $\delta^{15} \mathrm{~N}$ is widely considered a reliable proxy of the trophic position occupied by the species (DeNiro \& Epstein 1981, Post 2002). The isotopic niche is the area occupied by the species in a bivariate $\delta$-space, where isotopic values are represented as coordinates, and might be considered a suitable surrogate of trophic niche (Jackson et al. 2011).

Isotopic determinations were conducted in skin biopsies from striped (Stenella coeruleoalba, $\mathrm{n}=90$ ) and common (Delphinus delphis, $\mathrm{n}=81$ ) dolphins stranded between 2001 and 2013. Skin is a metabolically active tissue with a relatively fast isotopic turnover (compared with other tissues such as muscle) and with a half-life of ca. $30 \mathrm{~d}$ (Giménez et al. 2016). Samples were oven-dried at $60^{\circ} \mathrm{C}$ for $48 \mathrm{~h}$ and powdered with a mortar and pestle. Lipids were removed from the samples before the isotopic determinations by sequential rinses with a 2:1 chloroform:methanol solution to avoid the skew in $\delta^{13} \mathrm{C}$ values (DeNiro \& Epstein 1978). Subsamples of powdered material $(0.3 \mathrm{mg})$ were weighed into tin capsules for isotopic determinations at the Laboratorio de Isótopos Estables of Estación Biológica de Doñana (LIE-EBD, Spain; www.ebd.csic.es/lie/index.html). All samples were combusted at $1020^{\circ} \mathrm{C}$ using a continuous flow isotope ratio mass spectrometry system by means of a Flash HT Plus elemental analyser coupled to a Delta-V Advantage isotope ratio mass spectrometer via a CONFLO IV interface (Thermo Fisher Scientific). The isotopic compositions are reported in the conventional delta

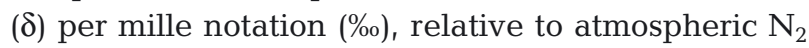
and Vienna Pee Dee Belemnite (Coplen 2011). Replicate assays of standards routinely inserted within the sampling sequence indicated analytical measurement errors of \pm 0.2 and $0.1 \%$ for $\delta^{15} \mathrm{~N}$ and $\delta^{13} \mathrm{C}$, respectively. The reference materials used were EBD-23 (cow horn), LIE-BB (whale baleen) and LIE-PA (razorbill feathers). These reference materials were previously calibrated with international certified materials supplied by the International Atomic Energy Agency.

\section{Intraspecific isotopic variation}

Previous studies based on stomach content and stable isotope analysis show evidence of ontogenetic, seasonal and geographical patterns in the diet of striped dolphins (Astruc 2005, Meissner et al. 2012).
Thus, we analysed the relationships between $\delta^{13} \mathrm{C}$ and $\delta^{15} \mathrm{~N}$, and several explanatory variables such as body length (as a proxy of age), sex, year and month through generalized additive models (GAMs; Hastie \& Tibshirani 1990). A Gaussian distribution and logit link function with gamma $=1.4$ was used to prevent overfitting (Wood 2006). Body length was fitted as a continuous variable, while sex, year and month were fitted as factors. Model selection was performed through a backward selection procedure and the optimal model was identified by Akaike's information criterion (AIC). The best model was chosen as the one with the lowest AIC value, in which all remaining explanatory variables have significant effects. The final model was checked to ensure normality and any obvious patterns in the residuals. All analyses were performed with R v. 3.2.1 (R Core Team 2015) and the mgcv library (Wood 2001).

Interspecific isotopic variation

The 6 different Layman metrics $\delta^{15} \mathrm{~N}$ range (NR), $\delta^{13} \mathrm{C}$ range $(\mathrm{CR})$, total area (TA), mean distance to centroid (CD), mean nearest neighbour distance (MNND) and standard deviation of nearest neighbour distance (SDNND) were used for comparisons of isotopic niches between the species (Layman et al. 2007). Methodology and ecological explanation for each metric is provided in the Supplement. Niche widths and isotopic niche overlap were also explored using a Bayesian approach based on multivariate ellipse-based metrics (Jackson et al. 2011). This approach avoids the influence of extreme values (outlier individuals), and thus is appropriate to identify the area within the bivariate $\delta$-space $\left(\delta^{13} \mathrm{C}\right.$ and $\delta^{15} \mathrm{~N}$ ) occupied by the 'typical' members of a population. This is particularly beneficial when comparing populations with different sample sizes (Jackson et al. 2011). The analysis generates standard ellipse areas (SEA), which are bivariate equivalents to standard deviations in univariate analysis. A corrected SEA value $\left(\mathrm{SEA}_{\mathrm{c}}\right)$, which minimizes bias due to sample sizes, was graphically expressed (Jackson et al. 2011). SEA $A_{B}$ (Bayesian SEA) was also calculated using 10000 posterior draws to statistically compare niche width between species, calculating the proportion of ellipses smaller or larger than the others. All metrics were calculated with the R package 'siar' (Parnell et al. 2010), excluding calves, due to the nursing influence in the isotopic signature (e.g. Meissner et al. 2012). The inflexion point in stable isotope analyses was used as an indicator of the end 
of the nursing period. All years were pooled as the sample size precludes performing niche metrics by year, so these metrics have to be seen as a timeintegrated approach.

\section{Spatial modelling}

Density surface modelling

Density surface modelling is an alternative tool to conventional design-based line transect sampling used to estimate abundance of animals (e.g. Gómez de Segura et al. 2007, Notarbartolo di Sciara et al. 2015). Its advantages reside in the combination of line transect sampling with spatial analysis to predict animal abundance based on the relationship of animals observed with environmental factors, as well as taking into account the probability of detecting animals (Hedley et al. 1999, Buckland et al. 2004). Additionally, transect lines are not required to achieve equal coverage probability, being an appropriate method for analysing data collected from surveys with nonsystematic designs (Buckland et al. 2004). Here, data collected on the RV 'Toftevaag' from 1992 to 2009 in the Alboran Sea were used for these models. Data were filtered for summer months, when major sampling effort was performed. A total of 1072 sightings of common dolphins and 1306 of striped dolphins were available for analysis during $60616 \mathrm{~km}$ of tracks on-effort (with adequate searching conditions, i.e. sea state below 3 Douglas). The study area was divided into grid cells of $2 \times 2^{\prime}$ latitude-longitude of resolution, characterized according to several spatial and environmental variables (latitude, longitude, depth, standard deviation of depth, slope, distance from coast and from several isobaths, chl $a$, sea surface temperature (SST) and primary productivity, as in Cañadas \& Hammond 2006, 2008). We divided all oneffort transects into small segments (average $2.8 \mathrm{~km}$ ) with a homogeneous type of effort along them and little variability in environmental features within them. Model-based abundance estimates were performed following the methodology of Cañadas \& Hammond $(2006,2008)$. The following 5 steps were performed:

(1) Estimation of the detection function from the distance data and covariates that could affect detection probability. The software DISTANCE 6.0 was used to estimate the detection functions for each species, using the multiple covariate distance sampling (MCDS) method (Marques 2001, Thomas et al. 2002). Covariates considered for inclusion in the detection functions were effort-related (ship, observation plat- form height, position of observer, speed of vessel, sea state, swell height, sightability conditions) in order to apply the effective strip width (ESW) to all on-effort segments.

(2) Estimation of the ESW in each segment from the detection function equation and the covariates involved.

(3) Modelling the abundance of groups. The response variable used to formulate the spatial models of abundance of groups was the count of groups (N) in each segment (Hedley et al. 1999) using a generalized additive model (GAM) with a logarithmic link function and a Tweedie error distribution, with a parameter $\mathrm{p}=1.1$, very close to a Poisson distribution but with some overdispersion.

(4) Modelling of group size. Group size was also modelled using a GAM with a logarithmic link function. The response variable was the number of individuals counted in each group. Given the large overdispersion due to the wide range of group sizes (1 to 1000), a quasi-Poisson error distribution was used, with the variance proportional to the mean. See equations and their description in Cañadas \& Hammond (2008).

(5) Combination of steps (3) and (4), and extrapolation to the whole study area to obtain the final density of animals. The estimated abundance of animals for each grid cell was calculated as the product of its predicted abundance of groups and its predicted group size in each cell.

All models were fitted using package 'mgcv' version 1.7 for R (Wood 2001). Model selection was done manually using 3 diagnostic indicators: (1) the generalized cross validation score (GCV), an approximation of AIC (Wood 2001); (2) the percentage of deviance explained; and (3) the probability that each variable was included in the model by chance.

Identification of high-density areas and spatial overlap

For the identification of high-density areas for each species, we adapted the methodology of Cañadas \& Vázquez (2014), where cells covering the highest $40 \%$ of abundance in the whole distribution area were selected as core areas. To determine where the overlap between species begins, core areas of distribution were calculated for every $0.01 \%$ step of cumulative abundance. The spatial overlap between depicted core areas was subsequently assessed by determining the relative number of grid cells shared by both species with respect to their whole core spatial distribution, with values ranging from 0 (complete segregation) to 100 (complete overlap). 


\section{RESULTS}

\section{Trophic segregation}

Intraspecific variation in stable isotope values

The fitted model for $\delta^{15} \mathrm{~N}$ values in striped dolphins retained only body length as a significant variable explaining $74.4 \%$ of the deviance. A continuous decrease of $\delta^{15} \mathrm{~N}$ was observed for individuals measuring 760 to $1550 \mathrm{~mm}$, while this increased progressively in individuals from 1550 up to $2390 \mathrm{~mm}$ (Fig. 1, Tables S1 \& S2 in the Supplement at www.int-res. com/articles/suppl/m567p199_supp.pdf). The nitrogen stable isotope signature decreased by $2.7 \%$ between dolphins of 760 and $1550 \mathrm{~mm}$, and increased by $1.1 \%$ between 1550 and $2390 \mathrm{~mm}$. Calves had the highest predicted value, $1.6 \%$ higher than the value for adults. Likewise, for common dolphins, the fitted model for $\delta^{15} \mathrm{~N}$ retained only body length, explaining $44.7 \%$ of the deviance. In this case, a general decrease was observed between 945 and $2040 \mathrm{~mm}$ without any inflexion point. However, at around $1500 \mathrm{~mm}$ the curve seems to stabilize, almost arriving at an asymptote. The nitrogen stable signature decreased by $1.73 \%$ between the smallest and largest dolphins (Fig. 1).

The fitted model for $\delta^{13} \mathrm{C}$ in striped dolphins retained body length, sex and year as significant variables, explaining $69.1 \%$ of the deviance. Carbon stable isotope ratios decreased with increasing length for individuals between 760 and $1485 \mathrm{~mm}$, and from this length until $2390 \mathrm{~mm}$ a continuous increase was observed (Fig. 1, Table S2). On average, the carbon stable isotope composition decreased by $1.05 \%$ between dolphins of 760 and $1485 \mathrm{~mm}$, and increased by $0.75 \%$ between 1485 and $2390 \mathrm{~mm}$. The difference between the highest predicted value for calves and the highest predicted value for adults was $0.29 \%$. In contrast, for common dolphins, the fitted model for $\delta^{13} \mathrm{C}$ values retained only year as a significant variable, explaining $56.4 \%$ of the deviance. In this case, a non-significant slight decrease was observed in individuals between 760 and $1485 \mathrm{~mm}$ long (Fig. 1).
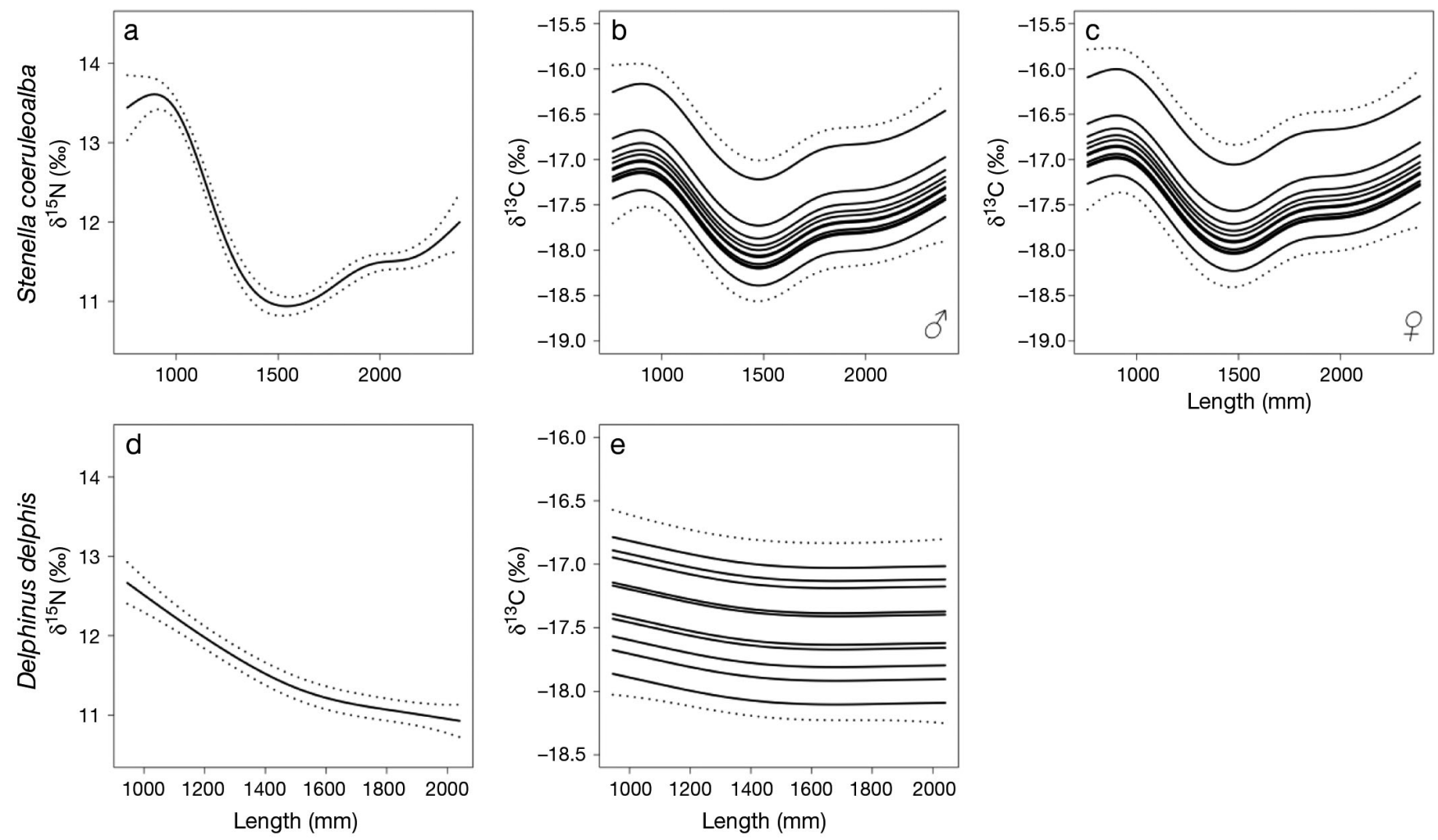

Fig. 1. Intraspecific isotopic variation. (a) Effect of striped dolphin Stenella coeruleoalba length on nitrogen stable isotope signature. $(b, c)$ Effect of striped dolphin length, sex and year on carbon stable isotope signature. (d) Effect of common dolphin Delphinus delphis length on nitrogen stable isotope signature. (e) Effect of common dolphin length and year on carbon stable isotope signature. The solid lines are the estimated smoothers. In (b), (c) and (e), each solid line represents a year. The dashed lines are the $95 \%$ confidence intervals 
Interspecific variation in stable isotopes: isotopic niche metrics

Common dolphins have higher probabilities than striped dolphins of having higher values for most of the isotopic niche metrics considered (i.e. $\mathrm{SEA}_{\mathrm{B}}, \mathrm{CD}$, MNND, SDNND). However, this trend is opposite for those metrics that are strongly influenced by extreme values $\left(\delta^{13} \mathrm{C}\right.$ range, $\delta^{15} \mathrm{~N}$ range and TA; Fig. 2, Table S3 in the Supplement). Both species show similar niche spaces with a high overlap in the $\mathrm{SEA}_{c}(45.98$ and $74.61 \%)$ and convex hull areas (74.99 and $73.93 \%$ ) for common and striped dolphins, respectively (Fig. 3).

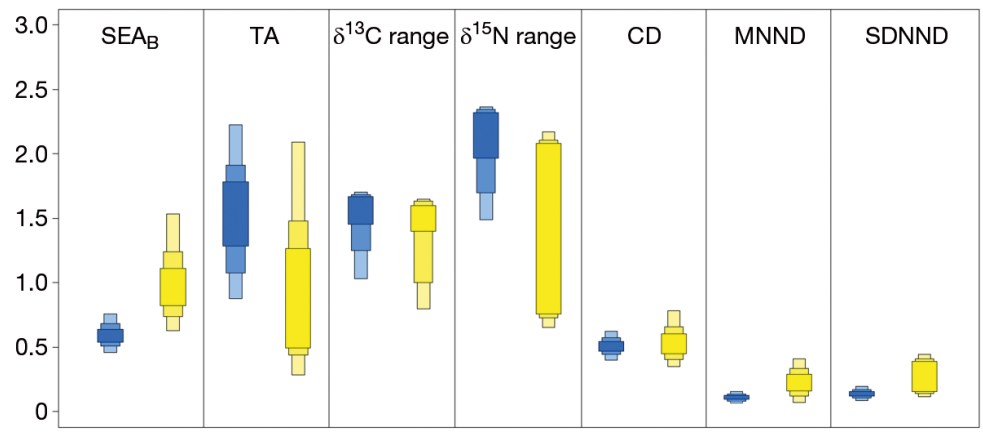

Fig. 2. Density plots showing the isotopic niche metrics: Bayesian standard ellipse area $\left(\mathrm{SEA}_{\mathrm{B}}\right)$; total area $(\mathrm{TA})$; carbon stable isotope range $\left(\delta^{13} \mathrm{C}\right.$ range); nitrogen stable isotope range $\left(\delta^{15} \mathrm{~N}\right.$ range); mean distance to centroid $(\mathrm{CD})$; mean nearest neighbour distance (MNND); and standard deviation of the nearest neighbour distance (SDNND). Striped dolphins Stenella coeruleoalba are shown in blue and common dolphins Delphinus delphis in yellow. The boxed areas reflect the 95, 75 and 50\% credible intervals for $\mathrm{SEA}_{B}$ and the confidence intervals for the rest of metrics

\section{Spatial segregation}

Spatial distribution

The final model of abundance of groups for common dolphins retained SST and the logarithm of depth as an interaction, and the geographic covariates latitude and longitude, all highly significant, explaining $8 \%$ of the deviance. The final model for group sizes of common dolphins retained SST and depth, both highly significant and explaining $12.4 \%$ of the deviance. The smoothed functions for the covariates in each model are shown in Figs. S2 \& S3 in the Supplement, respectively. The 2D plots of interaction between 2 covariates show how the effect of one covariate interacts with the effect of the other. In the interaction plot in Fig. S2, the smallest logarithm of depth (shallowest waters) has a negative effect on the density of groups, especially in intermediate SST, while the most positive effect is in lower SST and deeper waters.

The final model of abundance of groups for striped dolphins retained depth and latitude-longitude interactions, all highly significant, explaining $16.3 \%$ of the deviance. The final model for group sizes of striped dolphins retained the same covariates as the model of abundance of groups, all highly significant and explaining $8 \%$ of the deviance. The smoothed functions for the covariates in each model are shown in Figs. S4 \& S5 in the Supplement, respectively.

Common dolphin core area is more coastal than that for striped dolphins, with a higher density of animals towards the west and around the shelf break. Otherwise, striped dolphin density is very low close to the shore, beginning to increase at the shelf break towards oceanic waters. The main density area is located in the western part of the Alboran Sea in the vicinity of the Strait of Gibraltar (Fig. S6 in the Supplement).

\section{Spatial overlap}

The accumulated abundance threshold of $28 \%$ determines the minimum value for spatial overlap

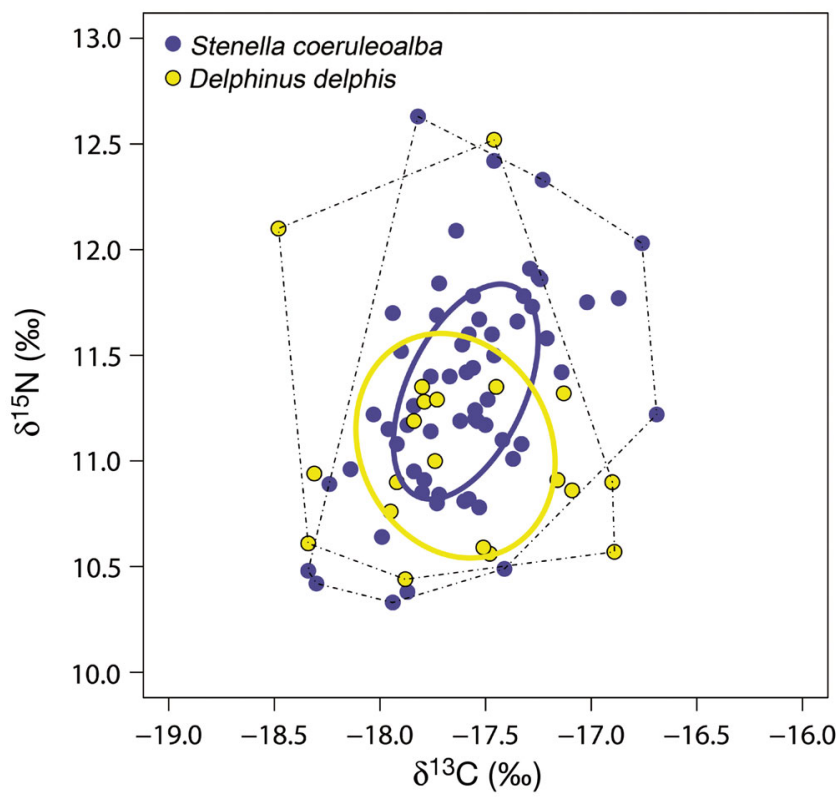

Fig. 3. Standard ellipse area corrected ( $\mathrm{SEA}_{c i}$ solid lines) and convex hull area (TA; dotted line). Striped dolphins Stenella coeruleoalba are shown in blue and common dolphins Delphinus delphis in yellow 

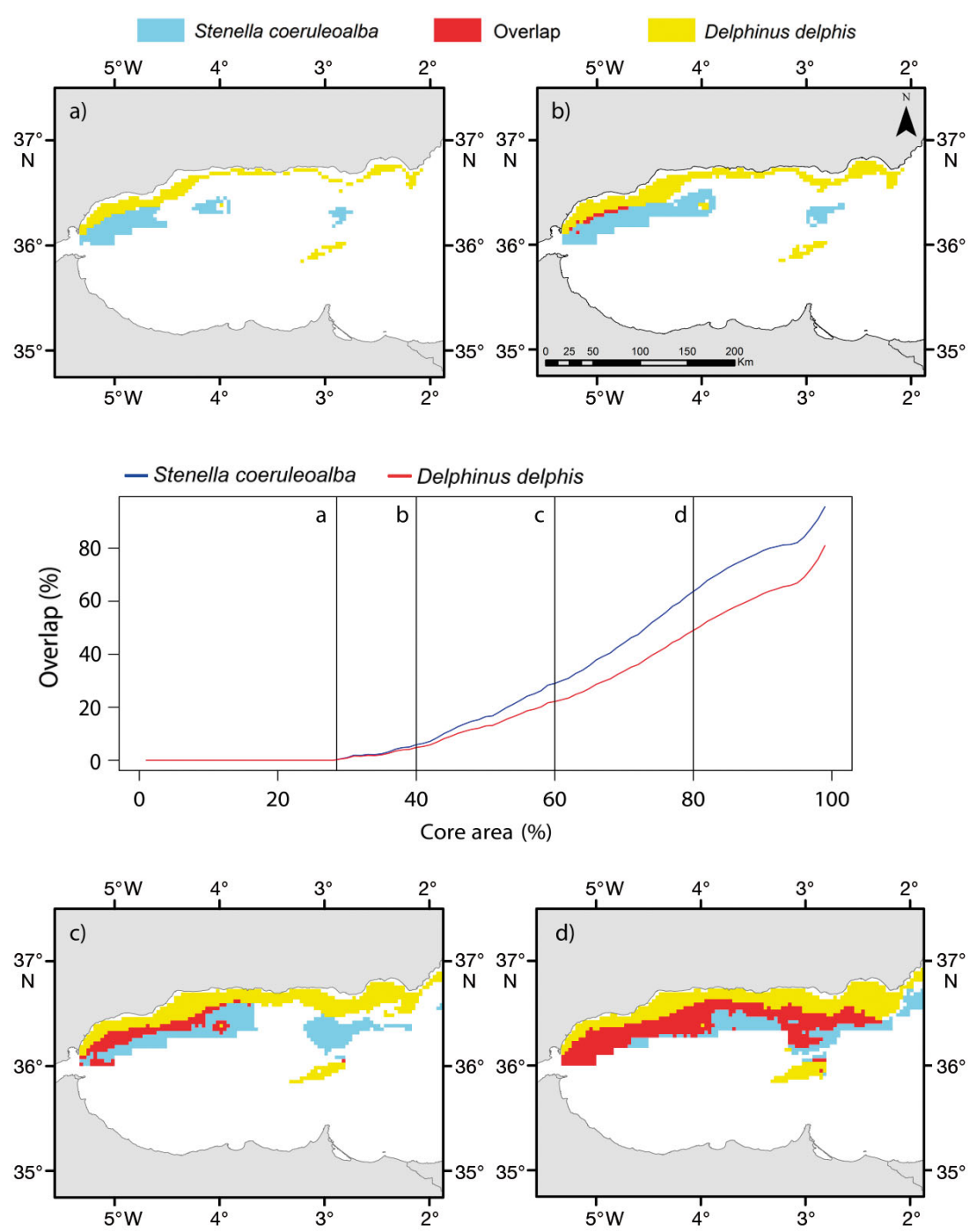

Fig. 4. Spatial overlap between striped Stenella coeruleoalba and common dolphins Delphinus delphis in the Alboran Sea. The middle panel shows how overlap increases when a different core area is selected, corresponding to (a), (b), (c) and (d)

between species. High-abundance core areas are clearly segregated in space and never overlap completely (Fig. 4). The $40 \%$ threshold used in Cañadas \& Vázquez (2014) for defining protected areas for cetaceans is also suitable for our study, as it represents a threshold in the initial overlap distribution between species (Fig. 4b). In this scenario, overlap distribution area reaches only 4.8 and $5.9 \%$ of the total area for the common and striped dolphin, respectively. Both species overlap at the western side of their distribution areas, close to the Strait of Gibraltar, covering $188 \mathrm{~km}^{2}$, with a depth of $496 \pm$ $56.06 \mathrm{~m}$ (mean $\pm \mathrm{SD}$; range: $315-798 \mathrm{~m}$ ), and coinciding with the area of highest density for both species

\section{DISCUSSION}

Species co-occurrence necessarily involves niche partitioning via trophic, spatial and/or temporal segregation (Gause 1934, Hutchinson 1957, Pianka 1976). In this study, spatial segregation was found as the main enabler for the coexistence of common and striped dolphins in the Alboran Sea. In particular, common dolphins occupy more coastal waters than striped dolphins. Our isotopic analyses suggested that common dolphins are more generalist and occupy a wider trophic niche than striped dolphins. This might be partially driven by trophic segregation among conspecifics. Nevertheless, we detected only ontogenetic dietary changes in striped dolphins with minimal sex-related trophic niche segregation. Overall, we observed a high overlap in the isotopic niche spaces of both species in the Alboran Sea, as for the northeastern Atlantic (Das et al. 2000), but in contrast with the small overlap found previously by Borrell \& Aguilar (2005) in the Alboran Sea. Although the isotopic similarity found in the present study suggests that the 2 species are now occupying similar trophic niches, we cannot completely rule out the possibility that these species also segregate trophically. In this sense, isotopic similarity does not necessarily mean dietary similarity, as different food resources may show similar isotopic composition (Moreno et al. 2010, Ramírez et al. 2011). Indeed, previous studies report differences in the ecological strategies of these 2 species in the North Atlantic, i.e. common dolphins feed on high-quality food with a corresponding high metabolic cost of living, while striped dolphins are characterized by moderate metabolic cost of living and quality of food (Spitz et al. 2012).

At the intraspecific level, variations in $\delta^{15} \mathrm{~N}$ and $\delta^{13} \mathrm{C}$ values in relation to body length point to ontogenetic changes in the diet of striped dolphins (Meissner et al. 2012). The observed decrease in $\delta^{15} \mathrm{~N}$ and $\delta^{13} \mathrm{C}$ values up to a body length of ca. $1500 \mathrm{~mm}$ (when weaning typically occurs; Meissner et al. 2012) is in accordance with a change from milk to a fishor cephalopod-based diet (Steele \& Daniel 1978, Hobson et al. 1997, Das et al. 2003, Knoff et al. 2008, Fernández et al. 2011). The observed continuous rise 
in $\delta^{15} \mathrm{~N}$ and $\delta^{13} \mathrm{C}$ values as body length increases in weaned individuals points to dietary changes among different age classes, with older individuals consuming larger prey enriched in ${ }^{13} \mathrm{C}$ and ${ }^{15} \mathrm{~N}$ (Meissner et al. 2012). This suggests that trophic segregation may also occur at the intraspecific level in weaned animals and points to the inaccuracy of considering conspecifics as ecological equivalents. Indeed, stomach content analysis of Atlantic individuals indicates that larger individuals feed on larger prey (Ringelstein et al. 2006). Notwithstanding, in the northwestern Mediterranean, the diet composition of striped dolphins changes with maturity, with a shift in proportion from fish to isotopically enriched cephalopods (Astruc 2005). In contrast, isotopic changes between calves and adults of common dolphins are not so obvious, thus suggesting that weaning may be more progressive in this species. Nevertheless, $\delta^{15} \mathrm{~N}$ and $\delta^{13} \mathrm{C}$ values reach an asymptote in individuals larger than $1500 \mathrm{~mm}$. This suggests that weaning may also occur at this body size and individuals may maintain an isotopically stable diet when weaned.

In addition, conspecifics can reduce competition via resource partitioning by sex (e.g. Schoener 1974, Hobson et al. 1997, Das et al. 2003, Browning et al. 2014). In this study, sex seems to have only a minor influence on carbon stable values in striped dolphins. Thus, it seems that this species does not show sexspecific differences in its trophic niches in the Alboran Sea. In contrast, female striped dolphins from the northwestern Mediterranean Sea are enriched in nitrogen stable isotopes, suggesting different nutritional and energetic requirements for females (Gómez-Campos et al. 2011). Finally, it seems that certain year-to-year variation exists in the carbon stable isotope in both species, indicating possible changes in productivity or food availability in the area, which deserves further research.

At the interspecific level, the isotopic-wide measures of trophic diversity that are not influenced by extreme data points (i.e. $\mathrm{SEA}_{c}$ and $\mathrm{CD}$ ) indicate that common dolphins have a wider isotopic niche with a higher trophic diversity. Therefore, common dolphins seem to be more generalist, consuming a wider variety of isotopically different species. Furthermore, NND and SDNND metrics, which reflect the relative position of individuals to each other within the niche space and are used as a measure of trophic redundancy, indicate that common dolphins present a smaller trophic redundancy (individuals with dissimilar trophic ecologies) and a more uneven trophic niche (uneven individual packing) than striped dolphins (sensu Layman et al. 2007).
The high overlaps between $\mathrm{SEA}_{\mathrm{c}}$ and convex hull areas indicate a large isotopic niche overlap between the species. Stomach content analyses of striped dolphins in the Mediterranean Sea show that they are generalist feeders, generally exploiting a wide variety of oceanic, pelagic and bathypelagic preys, which form large and dense shoals in the water column (Aguilar 2000). The species consumed include cephalopods from the families Histiotheuthidae, Ommastrephidae, Enoploteuthidae and Onychoteuthidae, and bony fish from the families Gadidae, Sparidae and Gonostomatidae (Wurtz \& Marrale 1991, Pulcini et al. 1992, Blanco et al. 1995, Meotti \& Podestà 1997). For common dolphins, the sparse information on the trophic ecology in the Mediterranean indicates relatively flexible feeding habits, with epipelagic and mesopelagic fish as preferred preys, such as the European anchovy Engraulis encrasicolus, the European pilchard Sardina pilchardus, the round sardinella Sardinella aurita and the garpike Belone belone, but also some eurybathic cephalopod and crustacean species (Orsi Relini \& Relini 1993, Boutiba \& Abdelghani 1995, Cañadas \& Sagarminaga 1996, Bearzi et al. 2003, Politi \& Bearzi 2004). Overall, it seems that striped and common dolphins are not competing for food resources in the Mediterranean Sea, although it must be noted that their diets slightly overlap (Bearzi et al. 2003). Additionally, contaminant loads in both species markedly differ, indicating possible dissimilar diets, different feeding areas and/or different abilities to handle pollutants (Borrell \& Aguilar 2005). Accordingly, we cannot unequivocally conclude that isotopic similarity between species is the result of trophic overlap, as they may be consuming different prey types with similar isotopic compositions. Further analyses (e.g. description of stomach contents) are therefore required to unequivocally point to trophic niche segregation as a potential enabler of species co-occurrence in the Mediterranean (as reported for the North Atlantic, Spitz et al. 2012)

In the Alboran Sea, mixed groups of common and striped dolphins account for $17 \%$ of all common dolphin sightings (García-Tiscar et al. 2000). These mixed groups are also present in other parts of the Mediterranean Sea (i.e. southern Tyrrenian Sea and the Gulf of Corinth) and it is assumed that the ratio between mixed and single species groups increases with decreasing abundance. As the number of common dolphins decreases, small groups begin to depend on striped dolphins and move to mixed groups (Frantzis \& Herzing 2002). Despite these mixed groups, common and striped dolphins seem to segre- 
gate spatially in the area, presenting different core spatial areas. Common dolphins tend to aggregate at areas from 200 to $400 \mathrm{~m}$ depth, with higher density of groups towards the cooler western waters and progressively lower towards the warmer eastern waters. However, group sizes are larger in the eastern part of the Alboran Sea, with medium SSTs, and are smaller on average towards the cooler western waters. As a result, the density of animals is higher in both areas; namely, at the westernmost end of the Alboran Sea, where there are more but smaller groups, and at the easternmost end (not including the Gulf of Vera) where there are fewer, but larger groups. However, striped dolphin distribution is not related to SST, but mainly to depth, generally preferring waters of 600-1800 m. Then, common dolphins are more coastal than striped dolphins, with only a small overlap at the borders of the core areas near the Strait of Gibraltar, where the density is high for both species. After presenting this broad compendium of results, we confirm that these species can partition their spatial niche to avoid competition in the Alboran Sea, whereas the trophic dimension should be further investigated.

Common dolphins appear to have been abundant and widespread all over the Mediterranean basin, but in the 1970s, their numbers began to decrease relatively quickly (Bearzi et al. 2003). Several factors may have contributed to the decline of common dolphins (i.e. overfishing of their main prey, habitat degradation, contamination, climate changes, bycatch) (Bearzi et al. 2003). Nevertheless, there is some speculation that the striped dolphin began to occupy the ecological niche of the common dolphin until its replacement (Viale 1985) in almost all of the Mediterranean Sea, with the exception of the Alboran Sea and some relict groups in the southeastern Tyrrhenian and eastern Ionian Seas (reviewed in Bearzi et al. 2003). Considering the results presented here, we suggest that the replacement hypothesis seems plausible, because the isotopic niches of both species are very similar and their habitats are contiguous. A possible replacement could have occurred if conditions had improved for striped dolphins, while deteriorating for common dolphins at the same time. Indeed, similar reciprocal faunal changes have occurred in different pairs of small cetaceans (e.g. Shane 1994, Jefferson \& Schiro 1997, Palka et al. 1997). This begs the question: why has this replacement not taken place in the Alboran Sea? Population dynamics of common dolphins in the Alboran Sea are very different compared to the rest of the Mediterranean Sea. No general trend in abundance was observed in the Alboran Sea during the period between 1992 and 2004. However, on the other side of the Almeria-Oran front (Gulf of Vera), the numbers decreased threefold from 1992-1995 to 1996-2004 (Cañadas \& Hammond 2008). Furthermore, the Alboran Sea individuals are genetically more similar to their conspecifics of the Atlantic Ocean than those of the Mediterranean Sea (Natoli et al. 2008). The coexistence or the replacement of these species on both sides of the Almeria-Oran front may have been provoked by different oceanographic conditions, dissimilar rates of fishing exploitation, different environmental changes or a combination of these factors. Further research should focus on this topic to disentangle the true causes of these different scenarios.

In conclusion, common and striped dolphins seem to coexist in the Alboran Sea thanks to the core area spatial segregation. Nevertheless, whether niche segregation may also involve temporal (i.e. foraging at different times) or behavioural (i.e. using different foraging tactics, foraging at different depths) dimensions remains untested. Furthermore, future research should consider the variation in the isotopic composition of the prey and include stomach content analysis to better understand resource utilization of these species. Studies should be extended to the rest of the species of the Alboran Sea. Notwithstanding, stable isotope analyses in combination with spatial distribution models have proved to be useful tools for quantitative assessments on niche partitioning between co-occurring species.

Acknowledgements. We especially thank ALNITAK volunteers and research assistants that helped in the field work. Thanks to the Consejería de Agricultura, Pesca y Medio Ambiente and the Agencia de Medio Ambiente y Agua of the Junta de Andalucía for the sample collection as a part of their program Gestión sostenible del medio marino andaluz. Thanks also to the IFAW for providing the software Logger 2000. This work was funded by the Loro Parque Foundation, CEPSA, Ministerio de Medio Ambiente, Fundación Biodiversidad, LIFE+ Indemares (LIFE07NAT/E/000732) and LIFE Conservación de Cetáceos y tortugas de Murcia y Andalucía (LIFE02NAT/E/8610), and the EcoCet Project (CGL2011-25543). R.S. and J.G. were supported by the Spanish Ministry of Economy and Competitiveness, through the Severo Ochoa Programme for Centres of Excellence in R+D+I (SEV-2012-0262), and R.S. was also supported by the Subprograma Juan de la Cierva. Special thanks to Dr. Janiger (Curatorial Assistant [Mammals] from the Natural History Museum of Los Angeles County) for his extensive help with the bibliographic search to the marine mammologist community and to Dr. Moles for his valuable comments on the manuscript. 


\section{LITERATURE CITED}

Abrams P (1980) Some comments on measuring niche overlap. Ecology 61:44-49

Aguilar A (2000) Population biology, conservation threats and status of Mediterranean striped dolphins (Stenella coeruleoalba). J Cetacean Res Manag 2:17-26

Araújo MS, Bolnick DI, Layman CA (2011) The ecological causes of individual specialisation. Ecol Lett 14:948-958

Arin L, Anxelu X, Estrada M (2002) Phytoplankton size distribution and growth rates in the Alboran Sea (SW Mediterranean): short term variability related to mesoscale hydrodynamics. J Plankton Res 24:1019-1033

* Arthur KE, Boyle MC, Limpus CJ (2008) Ontogenetic changes in diet and habitat use in green sea turtle (Chelonia mydas) life history. Mar Ecol Prog Ser 362:303-311

Astruc G (2005) Exploitation des chaines trophiques marines de Mediterranee par les populations de cetaces. EPHE thesis, University of Montpellier

Bearhop S, Adams CE, Waldron S, Fuller RA, Macleod H (2004) Determining trophic niche width: a novel approach using stable isotope analysis. J Anim Ecol 73: 1007-1012

Bearhop S, Phillips RA, McGill R, Cherel Y, Dawson DA, Croxall JP (2006) Stable isotopes indicate sex-specific and long-term individual foraging specialisation in diving seabirds. Mar Ecol Prog Ser 311:157-164

Bearzi G, Reeves RR, Notarbartolo-di-Sciara G, Politi E, Cañadas A, Frantzis A, Mussi B (2003) Ecology, status and conservation of short-beaked common dolphins Delphinus delphis in the Mediterranean Sea. Mammal Rev 33:224-252

Blanco C, Aznar J, Raga JA (1995) Cephalopods in the diet of the striped dolphin Stenella coeruleoalba from the western Mediterranean during an epizootic in 1990. J Zool (Lond) 237:151-158

Bolnick DI, Svanbäck R, Fordyce JA, Yang LH, Davis JM, Hulsey CD, Forister ML (2003) The ecology of individuals: incidence and implications of individual specialization. Am Nat 161:1-28

Borrell A, Aguilar A (2005) Differences in DDT and PCB residues between common and striped dolphins from the southwestern Mediterranean. Arch Environ Contam Toxicol 48:501-508

Boutiba Z, Abdelghani F (1995) Food of the common dolphin (Delphinus delphis, L.) in Algerian waters. Eur Res Cetaceans 9:182

Browning NE, Cockcroft VG, Worthy GAJ (2014) Resource partitioning among South African delphinids. J Exp Mar Biol Ecol 457:15-21

Buckland S, Anderson D, Burnham K, Laake J, Borchers D, Thomas L (2004) Advance distance sampling: estimating abundance of biological populations. Oxford University Press, Oxford

Cañadas A (2006) Towards conservation of dolphins in the Alboran Sea. PhD thesis, Universidad Autónoma de Madrid

Cañadas A, Hammond PS (2006) Model-based abundance estimates for bottlenose dolphins off southern Spain: implications for conservation and management. J Cetacean Res Manag 8:13-27

Cañadas A, Hammond PS (2008) Abundance and habitat preferences of the short-beaked common dolphin Delphinus delphis in the southwestern Mediterranean: implications for conservation. Endang Species Res 4:309-331
Cañadas A, Sagarminaga R (1996) A long-term survey of distribution and dynamics of cetaceans along the southeastern coast of Spain: fourth year of research 19921995. Eur Res Cetaceans 10:125-129

Cañadas A, Vázquez JA (2014) Conserving Cuvier's beaked whales in the Alboran Sea (SW Mediterranean): identification of high density areas to be avoided by intense man-made sound. Biol Conserv 178:155-162

Colwell RK, Futuyma DJ (1971) On the measurement of niche breadth and overlap. Ecology 52:567-576

Coplen TB (2011) Guidelines and recommended terms for expression of stable-isotope-ratio and gas-ratio measurement results. Rapid Commun Mass Spectrom 25: 2538-2560

* Das K, Lepoint G, Loizeau V, Debacker V, Dauby P, Bouquegneau JM (2000) Tuna and dolphin associations in the north-east Atlantic: evidence of different ecological niches from stable isotope and heavy metal measurements. Mar Pollut Bull 40:102-109

* Das K, Lepoint G, Leroy Y, Bouquegneau JM (2003) Marine mammals from the southern North Sea: feeding ecology data from $\delta^{13} \mathrm{C}$ and $\delta^{15} \mathrm{~N}$ measurements. Mar Ecol Prog Ser 263:287-298

*DeNiro MJ, Epstein S (1978) Influence of diet on the distribution of carbon isotopes in animals. Geochim Cosmochim Acta 42:495-506

* DeNiro MJ, Epstein S (1981) Influence of diet on the distribution of nitrogen isotopes in animals. Geochim Cosmochim Acta 45:341-351

Durell SEA le V dit (2000) Individual feeding specialization in shorebirds: population consequences and conservation implications. Biol Rev Camb Philos Soc 75:503-518

*Fernández R, García-Tiscar S, Begoña Santos M, López A, Martínez-Cedeira JA, Newton J, Pierce GJ (2011) Stable isotope analysis in two sympatric populations of bottlenose dolphins Tursiops truncatus: evidence of resource partitioning? Mar Biol 158:1043-1055

*Forero MG, González-Solís J, Hobson KA, Donázar JA, Bertellotti M, Blanco G, Bortolotti GR (2005) Stable isotopes reveal trophic segregation by sex and age in the southern giant petrel in two different food webs. Mar Ecol Prog Ser 296:107-113

Frantzis A, Herzing DL (2002) Mixed-species associations of striped dolphins (Stenella coeruleoalba), short-beaked common dolphins (Delphinus delphis), and Risso's dolphins (Grampus griseus) in the Gulf of Corinth (Greece, Mediterranean Sea). Aquat Mamm 28:188-197

Fry B (2006) Stable isotope ecology. Springer, New York, NY García-Tiscar S, Knouse D, Sagarminaga R, Cañadas A (2000) An insight on the biological significance of mixed groups of common dolphins (Delphinus delphis) and striped dolphins (Stenella coeruleoalba) in the Alboran Sea. Eur Res Cetaceans 14:135-137

Gascard JC, Richez C (1985) Water masses and circulation in the western Alboran Sea and in the Straits of Gibraltar. Prog Oceanogr 15:157-216

Gause GF (1934) The struggle for existence. Williams and Wilkins, Baltimore, MD

Geange SW, Pledger S, Burns KC, Shima JS (2011) A unified analysis of niche overlap incorporating data of different types. Methods Ecol Evol 2:175-184

Giménez J, Ramírez F, Almunia J, Forero MG, De Stephanis $\mathrm{R}$ (2016) Applicable isotope turnover rates and diet to skin discrimination factors for bottlenose dolphins (Tursiops truncatus). J Exp Mar Biol Ecol 475:54-61 
Gómez-Campos E, Borrell A, Cardona L, Forcada J, Aguilar A (2011) Overfishing of small pelagic fishes increases trophic overlap between immature and mature striped dolphins in the Mediterranean Sea. PLOS ONE 6:e24554

Gómez de Segura A, Hammond P, Cañadas A, Raga JA (2007) Comparing cetacean abundance estimates derived from spatial models and design-based line transect methods. Mar Ecol Prog Ser 329:289-299

Hastie T, Tibshirani R (1990) Generalized additive models, Chapman \& Hall/CRC, London

Hedley SL, Buckland ST, Borchers DL (1999) Spatial modelling from line transect data. J Cetacean Res Manag 1:255-264

* Hobson KA, Sease JL, Merrick RL, Piatt JF (1997) Investigating trophic relationships of pinnipeds in Alaska and Washington using stable isotope ratios of nitrogen and carbon. Mar Mamm Sci 13:114-132

*Huertas IE, Ríos AF, García-Lafuente J, Navarro G and others (2012) Atlantic forcing of the Mediterranean oligotrophy. Global Biogeochem Cycles 26:GB2022

*Hutchinson GE (1957) Concluding remarks. Cold Spring Harb Symp Quant Biol 22:415-427

Jackson AL, Inger R, Parnell AC, Bearhop S (2011) Comparing isotopic niche widths among and within communities: SIBER - Stable Isotope Bayesian Ellipses in R. J Anim Ecol 80:595-602

Jefferson TA, Schiro AJ (1997) Distribution of cetaceans in the offshore Gulf of Mexico. Mammal Rev 27:27-50

Knoff A, Hohn A, Macko S (2008) Ontogenetic diet changes in bottlenose dolphins (Tursiops truncatus) reflected through stable isotopes. Mar Mamm Sci 24:128-137

Kayman CA, Arrington DA, Montaña CG, Post DM (2007) Can stable isotope ratios provide for community-wide measures of trophic structure? Ecology 88:42-48

* Lukeneder A, Harzhauser M, Müllegger S, Piller WE (2010) Ontogeny and habitat change in Mesozoic cephalopods revealed by stable isotopes $\left(\delta^{18} \mathrm{O}, \delta^{13} \mathrm{C}\right)$. Earth Planet Sci Lett 296:103-114

Marques FFC (2001) Estimating wildlife distribution and abundance from line transect surveys conducted from platforms of opportunity. PhD thesis, University of St. Andrews

Meissner AM, MacLeod CD, Richard P, Ridoux V, Pierce G (2012) Feeding ecology of striped dolphins, Stenella coeruleoalba, in the north-western Mediterranean Sea based on stable isotope analyses. J Mar Biol Assoc UK 92:1677-1687

Méndez-Fernandez P, Pierce GJ, Bustamante P, Chouvelon $\mathrm{T}$ and others (2013) Ecological niche segregation among five toothed whale species off the NW Iberian Peninsula using ecological tracers as multi-approach. Mar Biol 160:2825-2840

Meotti C, Podestà M (1997) Stomach contents of striped dolphins, Stenella coeruleoalba (Meyen, 1833), from the western Ligurian Sea (Cetacea, Delphinidae). Atti Soc Sci Nat Mus Civ Stor Nat Milano 137:5-15

Moreno R, Jover L, Munilla I, Velando A, Sanpera C (2010) A three-isotope approach to disentangling the diet of a generalist consumer: the yellow-legged gull in northwest Spain. Mar Biol 157:545-553

Natoli A, Cañadas A, Vaquero C, Politi E, FernandezNavarro P, Hoelzel AR (2008) Conservation genetics of the short-beaked common dolphin (Delphinus delphis) in the Mediterranean Sea and in the eastern North Atlantic Ocean. Conserv Genet 9:1479-1487
Newsome SD, Martinez del Rio C, Bearhop S, Phillips DL (2007) A niche for isotopic ecology. Front Ecol Environ 5:429-436

Newsome SD, Tinker MT, Gill VA, Hoyt ZN, Doroff A, Nichol L, Bodkin JL (2015) The interaction of intraspecific competition and habitat on individual diet specialization: a near range-wide examination of sea otters. Oecologia 178:45-59

Notarbartolo di Sciara G, Lauriano G, Pierantonio N, Cañadas A, Donovan G, Panigada S (2015) The devil we don't know: investigating habitat and abundance of endangered giant devil rays in the north-western Mediterranean Sea. PLOS ONE 10:e0141189

Orsi Relini L, Relini M (1993) The stomach content of some common dolphins (Delphinus delphis L.) from the Ligurian Sea. Eur Res Cetaceans 7:99-102

Palka D, Read A, Potter CC (1997) Summary of knowledge of white-sided dolphins (Lagenorhynchus acutus) from US and Canadian Atlantic waters. Rep Int Whaling Comm 47:729-734

* Parnell AC, Inger R, Bearhop S, Jackson AL (2010) Source partitioning using stable isotopes: coping with too much variation. PLOS ONE 5:e9672

Parrilla G, Kinder TH (1987) Oceanografía física del mar de Alborán. Bol Inst Esp Oceanogr 4:133-165

Pianka ER (1976) Competition and niche theory. In: May RM (ed) Theoretical ecology: principles and applications. Blackwell, London, p 114-181

Politi E, Bearzi G (2004) Evidence of decline for a common dolphin community in the eastern Ionian Sea. Eur Res Cetaceans 15:449-452

*Post DM (2002) Using stable isotopes to estimate trophic position: models, methods, and assumptions. Ecology 83: 703-718

Pulcini M, Carlini R, Wurtz M (1992) Stomach contents of striped dolphins, Stenella coeruleoalba (Meyen, 1933), from the south-central Tyrrhenian coast. Eur Res Cetaceans 6:194-195

* R Core Team (2015) R: a language and environment for statistical computing. R Foundation for Statistical Computing, Vienna. http://www.R-project.org/

* Ramírez F, Abdennadher A, Sanpera C, Jover L, Wassenaar LI, Hobson KA (2011) Assessing waterbird habitat use in coastal evaporative systems using stable isotopes $\left(\delta^{13} \mathrm{C}\right.$, $\delta^{15} \mathrm{~N}$ and $\left.\delta \mathrm{D}\right)$ as environmental tracers. Estuar Coast Shelf Sci 92:217-222

* Ringelstein J, Pusineri C, Hassani S, Meynier L, Nicolas R, Ridoux V (2006) Food and feeding ecology of the striped dolphin, Stenella coeruleoalba, in the oceanic waters of the north-east Atlantic. J Mar Biol Assoc UK 86:909-918

Rodríguez J (1982) Oceanografia del mar Mediterráneo. Pirámide, Madrid

Kubenstein DR, Hobson KA (2004) From birds to butterflies: animal movement patterns and stable isotopes. Trends Ecol Evol 19:256-263

Rubín JP, Gil J, Ruiz J, Corté MD, Jiménez-Gómez F, Parada M, Rodríguez J (1992) La distribución ictioplanctónica y su relación con parámetros físicos, químicos y biológicos en el sector norte del mar de Alborán, en julio de 1991 (resultados de la campaña "Ictio. Alborán 0791"). Technical Report. Instituto Español de Oceanografia

Schoener TW (1974) Resource partitioning in ecological communities. Science 185:27-39

Shane SH (1994) Occurrence and habitat use of marine mammals at Santa Catalina Island, California from 1983- 
91. Bull South Calif Acad Sci 93:13-29

Spitz J, Trites AW, Becquet V, Brind'Amour A, Cherel Y, Galois R, Ridoux V (2012) Cost of living dictates what whales, dolphins and porpoises eat: the importance of prey quality on predator foraging strategies. PLOS ONE 7:e50096

Steele KW, Daniel RM (1978) Fractionation of nitrogen isotopes by animals: a further complication to the use of variations in the natural abundance of ${ }^{15} \mathrm{~N}$ for tracer studies. J Agric Sci 90:7-9

Templado J (1993) Fauna marina circalitoral del sur de la Península Ibérica: resultados de la campaña oceanográfica "Fauna I." . CSIC-CSIC Press, Madrid

Thomas L, Buckland S, Burnham K, Anderson D, Laake J, Borchers D, Strindberg S (2002) Distance sampling. In: ElShaarawi A, Piegorsch W (eds) Encyclopedia of envi-

Editorial responsibility: Yves Cherel, Villiers-en-Bois, France ronmetrics. John Wiley \& Sons, Chichester, p 544-552

* Tintoré J, La Violette PE, Blade I, Cruzado A (1988) A study of an intense density front in the eastern Alboran Sea: the Almeria-Oran Front. J Phys Oceanogr 18:1384-1397

Viale D (1985) Cetaceans in the northwestern Mediterranean: their place in the ecosystem. Oceanogr Mar Biol Annu Rev 23:491-571

Wood SN (2001) mgcv: GAMs and generalized ridge regression for R. R News 1:20-25

Whood SN (2006) On confidence intervals for generalized additive models based on penalized regression splines. Aust N Z J Stat 48:445-464

Wurtz M, Marrale D (1991) On the stomach contents of striped dolphins (Stenella coeruleoalba, Meyen 1933) from the Ligurian Coast, central Mediterranean Sea. Eur Res Cetaceans 5:62-64

Submitted: June 8, 2016; Accepted: January 3, 2016

Proofs received from author(s): March 4, 2017 


\title{
Intra- and interspecific niche partitioning in striped and common dolphins inhabiting the southwestern Mediterranean Sea
}

\author{
Joan Giménez*, Ana Cañadas, Francisco Ramírez, Isabel Afán, Susana García-Tiscar, Carolina \\ Fernández-Maldonado, Juan José Castillo, Renaud de Stephanis \\ *Corresponding author: gimenez.verdugo@gmail.com
}

Marine Ecology Progress Series 567: 199-210 (2017)

\section{SUPPLEMENTARY TEXT}

Six different Layman metrics were used as a measure of niche variation between the species (Layman, 2007):

1) $\delta^{15} \mathbf{N}$ Range (NR): Distance between the most enriched and most depleted $\delta^{15} \mathrm{~N}$ values (i.e., maximum $\delta^{15} \mathrm{~N}$ - minimum $\delta^{15} \mathrm{~N}$ ). NR is a representation of vertical structure. Trophic position of organisms must be calculated in relation to the $\delta^{15} \mathrm{~N}$ values of a standardized baseline (Post, 2002) but, generally, a larger range in $\delta^{15} \mathrm{~N}$ among consumers suggests more trophic levels and thus a greater degree of trophic diversity;

2) $\boldsymbol{\delta}^{13} \mathbf{C}$ range (CR): Distance between the most enriched and most depleted $\delta^{13} \mathrm{C}$ values (i.e., maximum $\delta^{13} \mathrm{C}$ minimum $\delta^{13} \mathrm{C}$ ). Increased $\mathrm{CR}$ would be expected if there are multiple basal resources with varying $\delta^{13} \mathrm{C}$ values;

3) Total area (TA): Convex hull area encompassed by all samples in $\delta^{13} \mathrm{C}-\delta^{15} \mathrm{~N}$ bi-plot space. This represents a measure of the total amount of niche space occupied, and thus a proxy for the total extent of trophic diversity within this group. TA is influenced by individuals with extreme positions on either the $\delta^{13} \mathrm{C}$ or $\delta^{15} \mathrm{~N}$ axis (or both), and thus typically will be correlated to some degree with these two metrics;

4) Mean distance to centroid (CD): Average euclidean distance of each sample to the $\delta^{13} \mathrm{C}-\delta^{15} \mathrm{~N}$ centroid. This metric provides a measure of the average degree of trophic diversity. In cases where a few outlier individuals may differentially affect TA, this measure may better reflect the overall degree of trophic diversity. However, this measure also is a function of the degree of individual spacing (see following metric);

5) Mean nearest neighbour distance (MNND): Mean of the euclidean distances to each individual' nearest neighbour in biplot space, and thus a measure of the overall density of individuals packing. Groups with a large proportion of individuals characterized by similar trophic ecologies will exhibit a smaller MNND (increased trophic redundancy) than a group in which individuals are, on average, more divergent in terms of their trophic niche;

6) Standard deviation of nearest neighbour distance (SDNND): A measure of the evenness of individuals packing in bi-plot space that is less influenced than MNND by sample size. Low SDNND values suggest more even distribution of trophic niches. All Layman metrics were bootstrapped with replacement $(n=10000)$ based on half of the sample size to obtain confidence intervals around each metric (Jackson et al., 2012). 


\section{FIGURES}

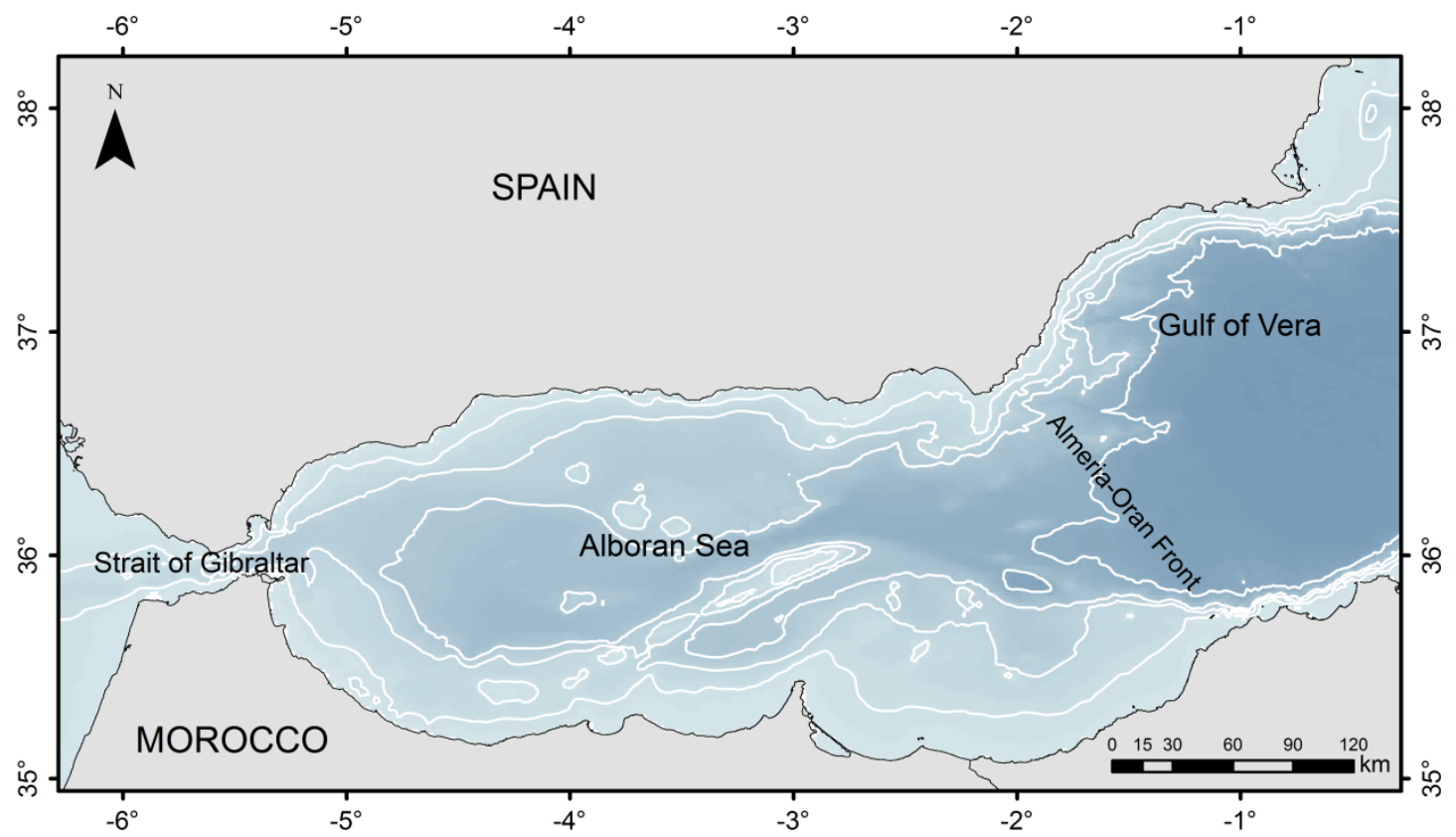

Figure S1: Study area map showing the Strait of Gibraltar, Alboran Sea, Gulf of Vera and Almeria-Oran front.
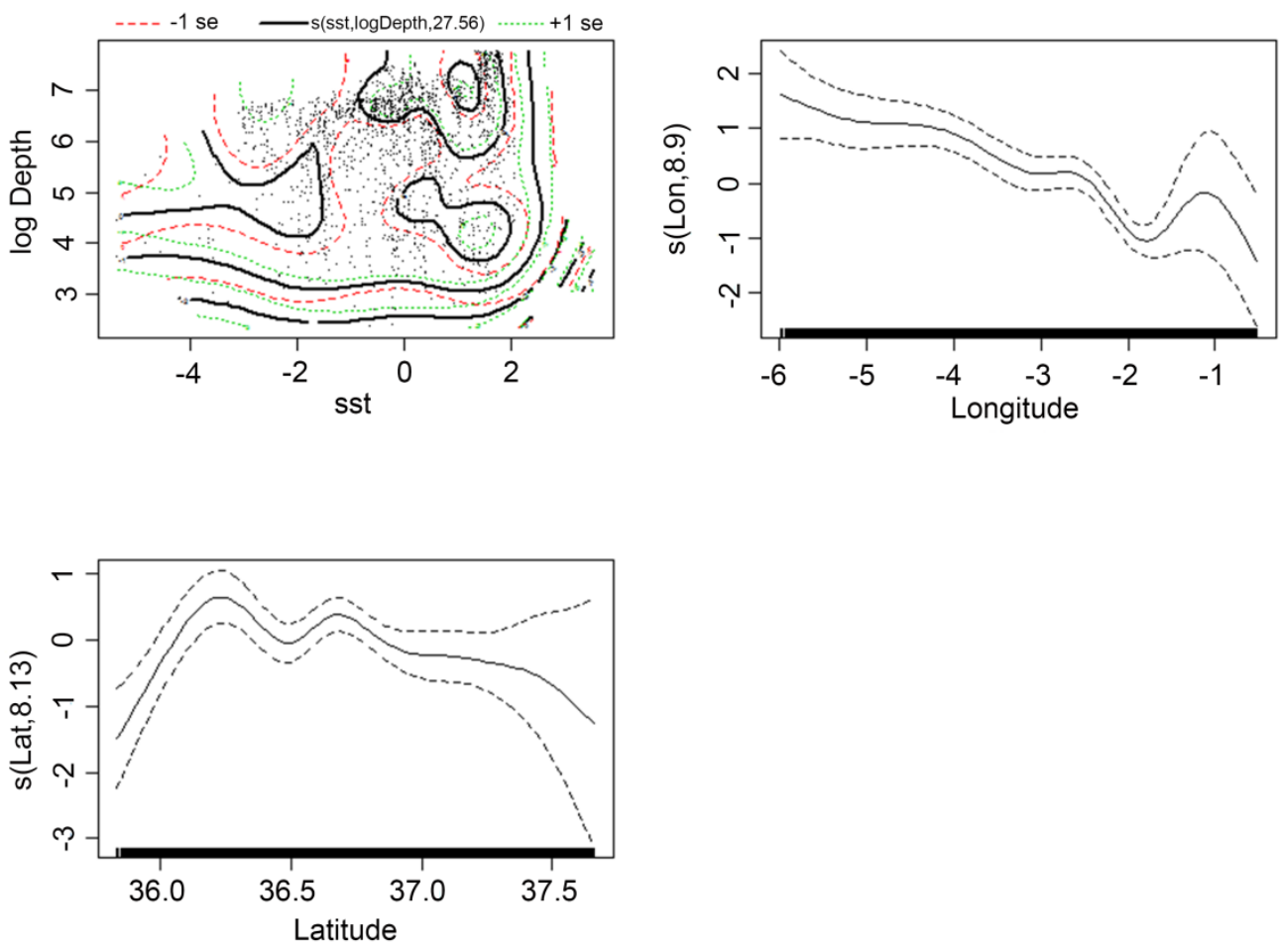

Figure S2: Shapes of the functional forms for the smoothed covariates used in the models for abundance of groups of common dolphins. Zero on the vertical axes corresponds to no effect of the covariate on the estimated response (group density). The dashed lines represent twice the standard errors of the estimated curve (95\% confidence band). The locations of the observations are plotted as small tick marks along the horizontal axes. The interactions between two variables are shown as two-dimensional plots. In these cases, the locations of the observations are plotted as small dots. The dotted red and green lines represent -1 standard 
error and +1 standard error respectively (equivalent to the dashed lines of the univariate plots). The number on the lines indicates whether it has a positive effect (e.g. '+1'), a negative effect (e.g. '-1') or is neutral ('0').
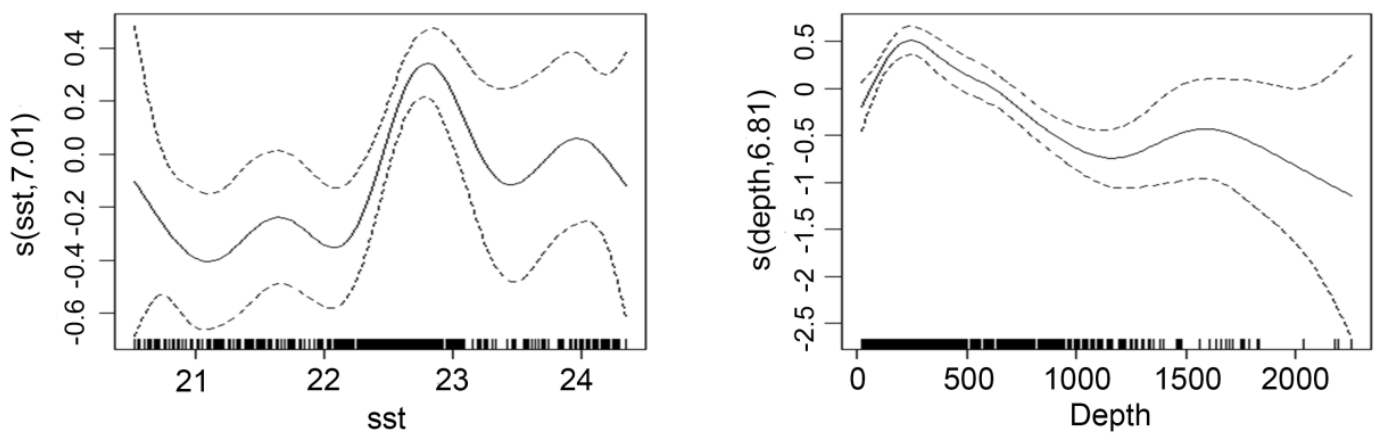

Figure S3: Shapes of the functional forms for the smoothed covariates used in the models for group sizes of common dolphins. Zero on the vertical axes corresponds to no effect of the covariate on the estimated response (group density). The dashed lines represent twice the standard errors of the estimated curve (95\% confidence band). The locations of the observations are plotted as small tick marks along the horizontal axes.
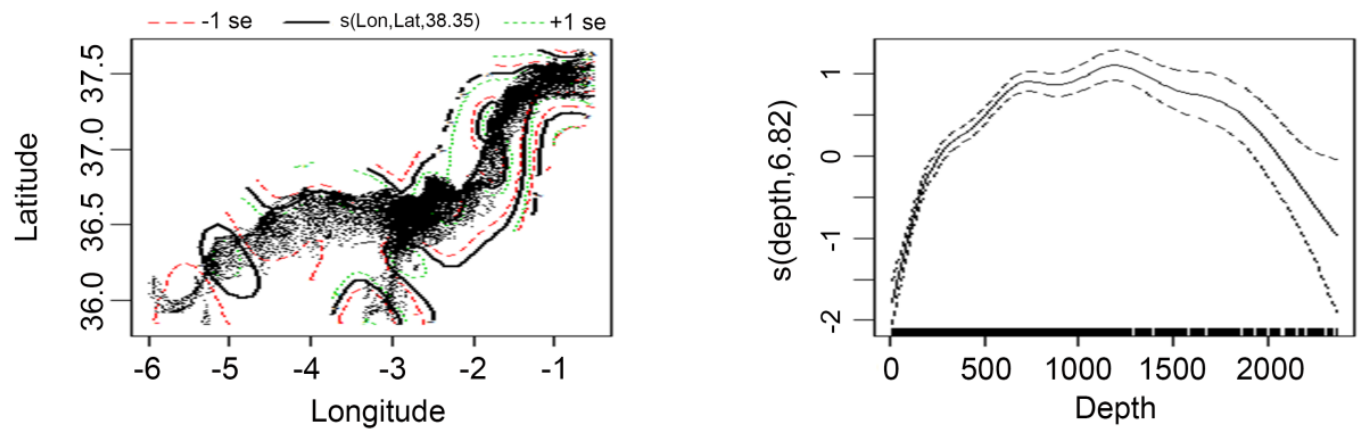

Figure S4: Shapes of the functional forms for the smoothed covariates used in the models for abundance of striped dolphins. Zero on the vertical axes corresponds to no effect of the covariate on the estimated response (group density). The dashed lines represent twice the standard errors of the estimated curve (95\% confidence band). The locations of the observations are plotted as small tick marks along the horizontal axes. The interactions between two variables are shown as two-dimensional plots. In these cases, the locations of the observations are plotted as small dots. The dotted red and green lines represent -1 standard error and +1 standard error, respectively (equivalent to the dashed lines of the univariate plots). The number on the lines indicates whether it has a positive effect (e.g. ' +1 '), a negative effect (e.g. '-1') or is neutral ('0'). 

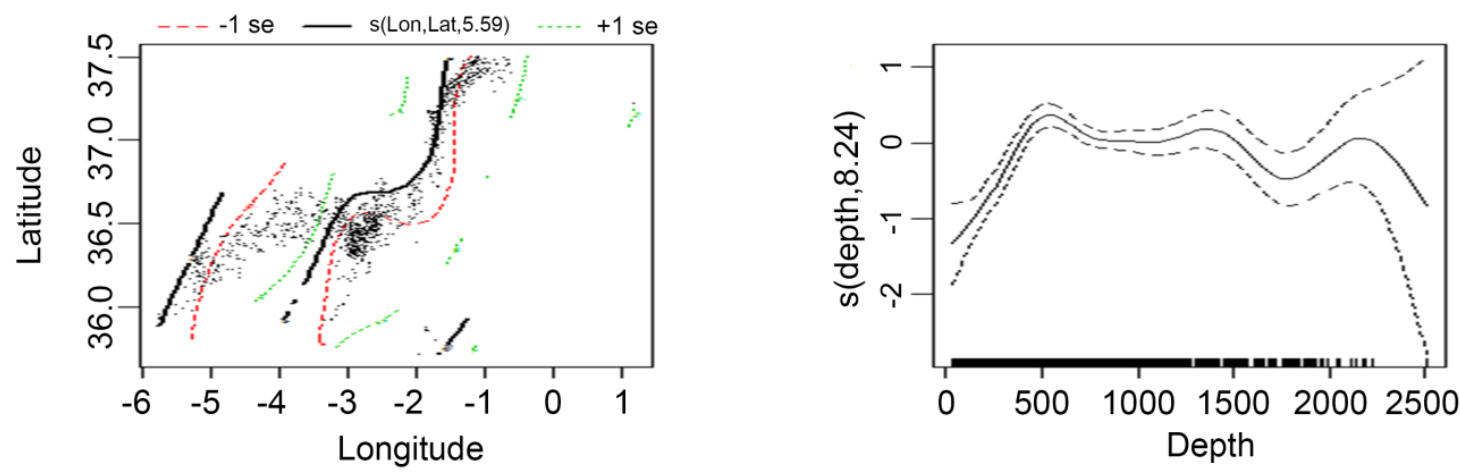

Figure S5: Shapes of the functional forms for the smoothed covariates used in the models for group sizes of striped dolphins. Zero on the vertical axes corresponds to no effect of the covariate on the estimated response (group density). The dashed lines represent twice the standard errors of the estimated curve (95\% confidence band). The locations of the observations are plotted as small tick marks along the horizontal axes. The interactions between two variables are shown as two-dimensional plots. In these cases, the locations of the observations are plotted as small dots. The dotted red and green lines represent -1 standard error and +1 standard error, respectively (equivalent to the dashed lines of the univariate plots). The number on the lines indicates whether it has a positive effect (e.g. ' +1 '), a negative effect (e.g. '-1') or is neutral ('0').

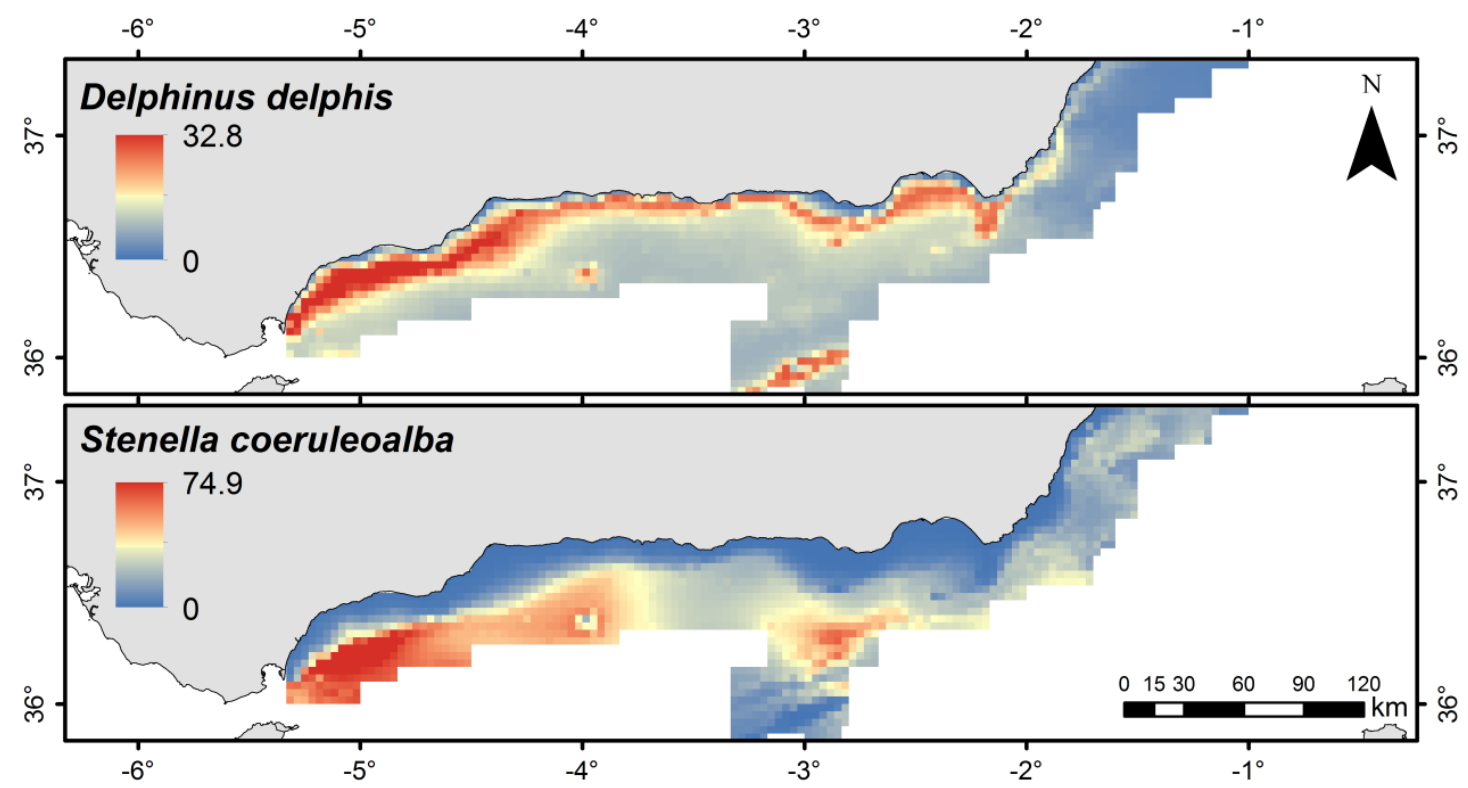

Figure S6: Spatial abundance distribution of common and striped dolphins in the Alboran Sea between 1992 and 2009. The prediction is presented in grid cells of $2 \times 2$ min latitude-longitude of resolution. High abundance areas in red versus low abundance areas in blue. 


\section{TABLES}

Table S1: Summary of samples analyzed for isotopic analysis split by month, year and sex. Mean $\delta^{15} \mathrm{~N}$ and $\delta^{13} \mathrm{C}$ values and its standard deviations are shown for each category.

Common dolphins

Striped dolphins

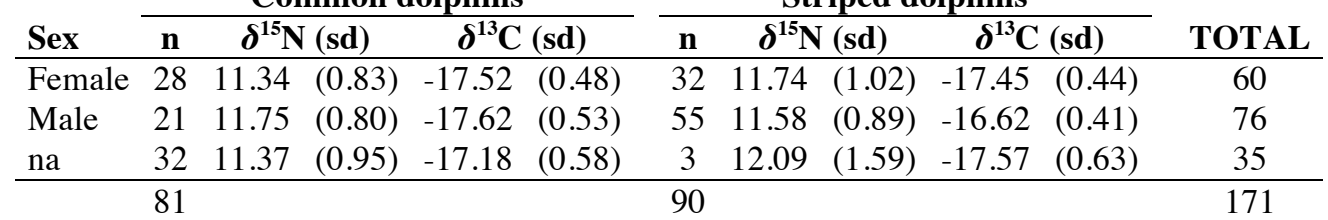

\begin{tabular}{|c|c|c|c|c|c|c|c|c|c|c|c|}
\hline \multirow[b]{2}{*}{ Month } & \multicolumn{5}{|c|}{ Common dolphins } & \multicolumn{5}{|c|}{ Striped dolphins } & \multirow[b]{2}{*}{ TOTAL } \\
\hline & n & $\delta^{15} \Lambda$ & (sd) & $\delta^{13} \mathrm{C}$ & (sd) & $\mathbf{n}$ & $\delta^{15} \uparrow$ & (sd) & $\delta^{13} \mathrm{C}$ & (sd) & \\
\hline 1 & 6 & 10.94 & $(0.53)$ & -17.59 & $(0.29)$ & 6 & 11.34 & $(0.35)$ & -17.46 & $(0.42)$ & 12 \\
\hline 2 & 4 & 11.00 & $(0.24)$ & -17.43 & $(0.50)$ & 11 & 11.57 & $(0.64)$ & -17.67 & $(0.27)$ & 15 \\
\hline 3 & 3 & 10.75 & $(0.31)$ & -17.51 & $(0.68)$ & 4 & 11.67 & $(0.66)$ & -17.51 & $(0.24)$ & 7 \\
\hline 4 & & & & & & 8 & 11.16 & $(0.48)$ & -17.75 & $(0.27)$ & 8 \\
\hline 5 & 2 & 11.69 & $(1.52)$ & -17.42 & $(1.31)$ & 5 & 10.98 & $(0.43)$ & -17.79 & $(0.15)$ & 7 \\
\hline 6 & 4 & 12.11 & $(1.25)$ & -17.23 & $(0.39)$ & 5 & 11.01 & $(0.27)$ & -17.80 & $(0.48)$ & 9 \\
\hline 7 & 10 & 11.72 & $(0.87)$ & -17.71 & $(0.49)$ & 12 & 11.76 & $(1.23)$ & -17.59 & $(0.53)$ & 22 \\
\hline 8 & 12 & 11.69 & $(0.97)$ & -17.61 & $(0.67)$ & 15 & 12.33 & $(1.24)$ & -17.28 & $(0.50)$ & 27 \\
\hline 9 & 5 & 11.48 & $(0.88)$ & -17.58 & $(0.48)$ & 8 & 12.04 & $(1.12)$ & -17.45 & $(0.35)$ & 13 \\
\hline 10 & 2 & 12.11 & $(1.15)$ & -17.59 & $(0.21)$ & 6 & 11.54 & $(1.15)$ & -17.72 & $(0.53)$ & 8 \\
\hline 11 & 5 & 11.16 & $(0.35)$ & -17.76 & $(0.19)$ & 3 & 11.88 & $(0.47)$ & -17.53 & $(0.08)$ & 8 \\
\hline 12 & 2 & 11.14 & $(0.72)$ & -17.43 & $(0.70)$ & 7 & 11.51 & $(0.81)$ & -17.48 & $(0.55)$ & 9 \\
\hline na & 26 & 11.44 & $(0.94)$ & -17.07 & $(0.51)$ & & & & & & 26 \\
\hline
\end{tabular}

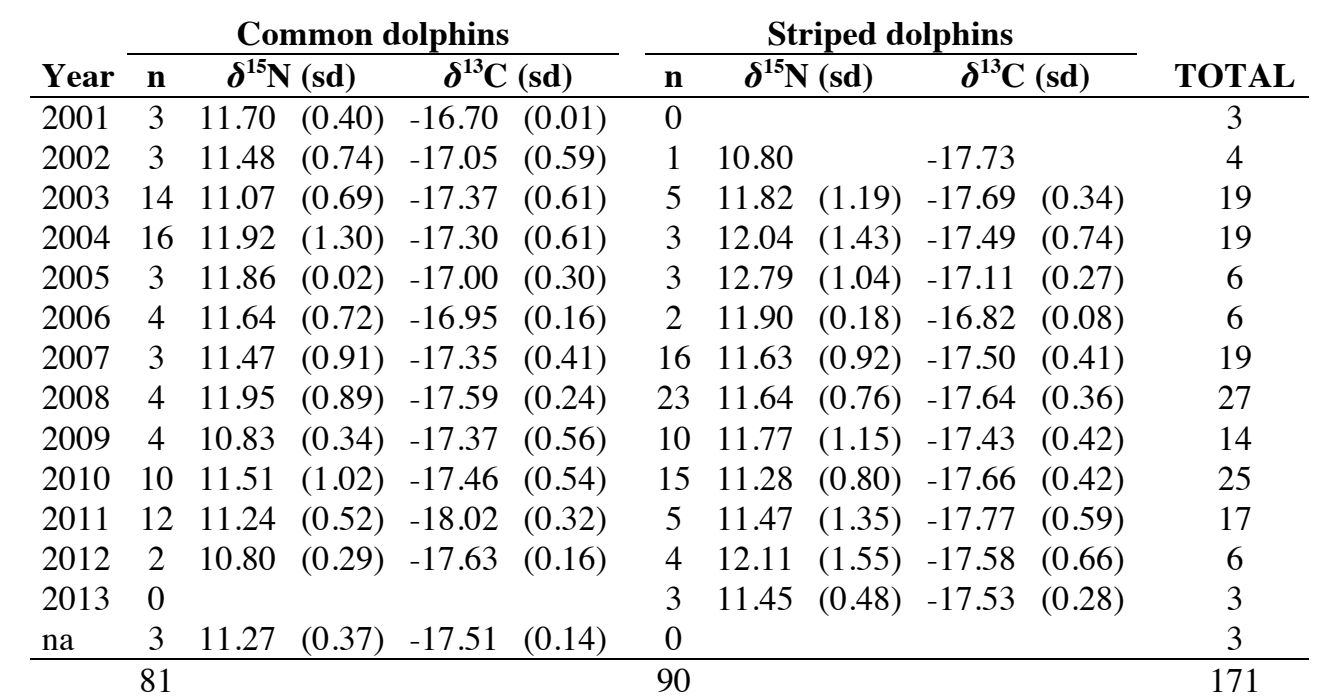


Table S2: Results of the GAM models for explaining striped and common dolphins stable isotope values. Explanatory variables, $\mathrm{R}^{2}$, deviance explained and Akaike Information Criterion (AIC) value for each model are given. Significant variables in each model are highlighted in bold and final models chosen (smallest AIC value with all significant variables in the model) are highlighted in grey.

\begin{tabular}{|c|c|c|c|c|}
\hline & & $\mathbf{R}^{2}$ & Deviance & AIC \\
\hline \multirow{8}{*}{ 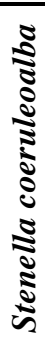 } & $\delta^{15} \mathrm{~N} \sim \mathbf{s}($ LENGTH $)+$ MONTH + YEAR + SEX & 0.750 & $83.10 \%$ & 135.22 \\
\hline & $\delta^{15} \mathbf{N} \sim \mathbf{S}($ LENGTH $)+$ MONTH + SEX & 0.750 & $80.20 \%$ & 129.18 \\
\hline & $\delta^{15} \mathrm{~N} \sim \mathbf{s}($ LENGTH $)+\mathrm{SEX}$ & 0.732 & $75.40 \%$ & 126.64 \\
\hline & $\delta^{15} \mathrm{~N} \sim \mathbf{s}$ (LENGTH) & 0.724 & $74.40 \%$ & 128.17 \\
\hline & $\delta^{13} \mathrm{C} \sim \mathbf{~ s}($ LENGTH $)+$ MONTH + YEAR + SEX & 0.573 & $70.80 \%$ & 46.73 \\
\hline & $\delta^{13} \mathbf{C} \sim \mathbf{s}($ LENGTH $)+$ YEAR + SEX & 0.611 & $69.10 \%$ & 32.82 \\
\hline & $\delta^{13} \mathrm{C} \sim \mathbf{S}($ LENGTH $)+$ YEAR & 0.593 & $67.40 \%$ & 36.22 \\
\hline & $\delta^{13} \mathbf{C} \sim \mathbf{S}($ LENGTH $)$ & 0.459 & $49.40 \%$ & 51.05 \\
\hline \multirow{8}{*}{ 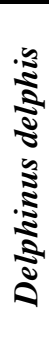 } & $\delta^{15} \mathrm{~N} \sim \mathbf{s}($ LENGTH $)+$ MONTH + YEAR + SEX & 0.382 & $67.70 \%$ & 106.44 \\
\hline & $\delta^{15} \mathrm{~N} \sim \mathbf{S}($ LENGTH $)+$ YEAR + SEX & 0.558 & $68.90 \%$ & 88.84 \\
\hline & $\delta^{15} \mathrm{~N} \sim \mathbf{s}($ LENGTH $)+\mathrm{SEX}$ & 0.44 & $47.70 \%$ & 92.00 \\
\hline & $\delta^{15} \mathrm{~N} \sim \mathbf{S}($ LENGTH $)$ & 0.422 & $44.70 \%$ & 92.39 \\
\hline & $\delta^{13} \mathrm{C} \sim \mathrm{s}($ LENGTH $)+\mathrm{MONTH}+$ YEAR + SEX & 0.299 & $63.40 \%$ & 62.39 \\
\hline & $\delta^{13} \mathrm{C} \sim \mathrm{s}($ LENGTH $)+$ YEAR $+\mathrm{SEX}$ & 0.408 & $56.20 \%$ & 51.29 \\
\hline & $\delta^{13} \mathrm{C} \sim \mathrm{s}($ LENGTH $)+$ YEAR & 0.428 & $56.40 \%$ & 49.17 \\
\hline & $\delta^{13} \mathrm{C} \sim \mathrm{s}($ LENGTH $)$ & 0.004 & $2.67 \%$ & 67.02 \\
\hline
\end{tabular}

Table S3: Isotopic niche metrics for striped and common dolphins. The subscript boot signifies that the value (mean) has been obtained through bootstrapping. Dde $=$ Delphinus delphis; Sco $=$ Stenella coeruleoalba .

Striped dolphin Common dolphin Probability

\begin{tabular}{lccc} 
& Striped dolphin & Common dolphin & Probability \\
\hline $\mathrm{SEA}_{\mathrm{c}}$ & 0.48 & 0.78 & \\
$\mathrm{SEA}_{\mathrm{B}}$ & 0.61 & 1.05 & $98.41 \%$ Dde $>$ Sco \\
\hline$\delta^{15} \mathrm{~N}$ range & 2.30 & 2.08 & \\
$\delta^{15} \mathrm{~N}_{\text {range }}$ & 1.99 & 1.47 & $80.50 \%$ Sco $>$ Dde \\
\hline$\delta^{13} \mathrm{C}$ range & 1.65 & 1.59 & \\
$\mathrm{~d}^{13} \mathrm{C}$ range & & & \\
boot & 1.42 & 1.32 & $62.88 \%$ Sco $>$ Dde \\
\hline $\mathrm{TA}$ & 2.42 & 2.39 & \\
$\mathrm{TA}$ & 1.54 & 1.07 & $79.36 \%$ Sco $>$ Dde \\
\hline $\mathrm{CD}$ & 0.52 & 0.58 & \\
$\mathrm{CD}$ & 0.51 & 0.55 & $61.30 \%$ Dde $>$ Sco \\
\hline $\mathrm{MNND}_{\text {boot }}$ & 0.11 & 0.26 & \\
$\mathrm{MNND}_{\text {boot }}$ & 0.11 & 0.24 & $91.52 \%$ Dde $>$ Sco \\
\hline $\mathrm{SDNND}_{\mathrm{SDNND}_{\text {boot }}}$ & 0.10 & 0.29 & \\
\hline
\end{tabular}

